\title{
An overview of CSR programs in Saudi Arabia with reference to select organizations
}

\author{
Samia Maqbool \\ Assistant Professor, Human Resource Management \\ King Abdulaziz University, Kingdom of Saudi Arabia \\ Email: samiamagbool@gmail.com
}

Doi:10.5296/ ijhrs.v5i2.7753 URL: http://dx.doi.org/10.5296/ ijhrs.v5i2.7753

\begin{abstract}
Corporate Social Responsibility (CSR) implies evaluation and taking the responsibility for the organization's impact on the larger environment and eventually the social welfare aspects. It refers to the promotion of positive social and environmental change. Organizations are crucial players in the community as well as the national economic development because they control huge assets and can invest for socially conscious investments and programs. Moreover, though customers may buy goods and services but ultimately today the level of competition depends on a number of factors like the corporations social programs. A company's public image is created mostly due to the CSR activities and how well-aware customers are of them. Employees like working for a company that has a good public image and is constantly in the media for positive reasons. This paper discusses the CSR activities of some select Saudi public and private companies and analyses the implications as well as the some of the positive suggestions and criticisms in the context of the kingdom.
\end{abstract}

Keywords: CSR; King Khalid Foundation; private sector; Saudi Arabia 


\section{Introduction}

Reverte (2009) had aptly discussed that in the last many years there has been an increase in public awareness about the significance of corporate social responsibility (CSR). The importance of CSR arose due to the growth in communication between various stakeholder groups and business organizations in society. The growing communication reflects the accountability of corporations in meeting their stakeholders ${ }^{\text {ee }}$ needs (Gray, Kouhy, \& Lavers, 1995). CSR is one of the vital success factors for business organizations in society who seek good image, sustained profitability and consistent corporate growth along with conducting socially responsible activities. This means that an organization should be held responsible for any of its activities that have an effect on citizens, communities, society at large, and the environment (Gustafson, 2002). Companies use CSR as a strategic weapon for competition in the era of globalization (Will, 2007). In a way, the concept of CSR is that companies have greater responsibilities than only to achieve a high profit for their shareholders. They should care about the society and act in a responsible way (Carroll \& Shabana, 2010). From the beginning of the twenty-first century it has become even more significant for companies to perform and act in a responsible manner according to the guidelines of CSR (Adams and Zutshi, 2004).

In today's dynamic world, Corporate Social Responsibility (CSR), is gaining immense importance for the various stakeholders of the society. CSR has taken strategic importance in the corporate world as well as other interest groups today. There is a deep relationship between the nation's growth and development and the CSR activities today. In the last few years Saudi Arabia had shown a meteoric economic rise. Initial plans of the kingdom emphasized on the gross domestic product (GDP) and its growth along with the development of the human resources and becoming less reliant on the non-oil sector. Nevertheless, research shows that the organizations in the Middle East are way behind. They seem to be incorporating CSR activities to illustrate their base in the market. The mind -set of the middle eastern organizations have made them only consider CSR programs in charitable events, donations without essentially implementing it as a core business strategy ( Lu, Wang and Lee,2013) . Ironically, organizations are still considering it as a tool to achieve a competitive edge over the other organizations in the domain of brand loyalty of the customers (Bondy, et al, 2012). In recent times, it is focusing less on consumer preferences and has been trying to address social and economic challenges that are preventing the development, especially the shortage of jobs (Shehadi \& Jamjoom, 2014). (http://www.strategy-business.com/article/00234?gko=b365d).

The most recent plans have focused on encouraging research, development and technological assimilation; promoting scientific activities; strengthening Saudi Arabia's role in the global economy; enhancing private-sector participation in the development process; expanding basic services offered to citizens; protecting the environment, natural resources and wildlife; and developing and conserving water resources, among other things (Ali \& Al-Aali, 2012). The objectives are now in collaboration with CSR ideologies. Herein is also evidenced the policy-makers' unflinching focus in forging successful partnerships with private enterprises and delivery of sustained results. The United Nations Industrial Development Organization 
(UNIDO, 2007) has reported that corporations in partnership with governments can make a vital contribution to developing innovative solutions to developmental challenges. Furthermore, in its study, "CSR and Developing Countries,"(2007) the UN's Division for Sustainable Development has argued that governments across the globe have promoted CSR to enhance national competitiveness and to help deliver public-policy goals and priorities. The Arab Forum for Environment and Development (AFED) has aptly stated that given the increasing challenges, "transitioning to the Green Economy is not only an option for the Arab region; rather it is an obligation to secure a proper path to sustainable development(Arab Forum for Environment \& Development, 2011).

In this paper I will study some select Saudi organizations that have been incessantly contributing towards the corporate social responsibility projects as there has been a significant development of the concept of CSR in the Kingdom during the last five years, especially increasing in the last two. The Saudi Arabian Responsible Competitiveness Index (SARCI) is an initiative taken by two Saudi organizations, one governmental and one semi-private, and one international non-governmental organization. The collaboration between these organizations might be one of the best examples of how important this concept has become in Saudi Arabia. That these important, but very different, actors in the field of CSR are collaborating to make the impact of the concept as powerful as possible could indicate that Saudi companies are considered to have an important role in the development of Saudi society.

The charity organization, King Khalid Foundation (KKF)is a charity organization based in Riyadh and was, according to the homepage of the organization, founded to achieve "the noble objectives, principles and values" that the late King Khalid bin Abdulaziz sought in service to the Saudis. The mission of the foundation is to make a positive impact in people's lives. This is to be done by working in partnerships to provide innovative solutions to critical social and economic challenges in Saudi Arabia. To strengthen the non-profit sector in the country by knowledge transfer, to improve community development efforts by providing funding, and to provide ongoing support for poor and disadvantaged communities in the Kingdom by funding emergency assistance projects are among the areas in which the foundation works.KKF is focused on social development and emphasizes the role of the private sector in this development. Among the advantages private companies have in contributing to social developments, KKF argues that this is linked directly to the workplace and that the leaders in the private sector tend to have a large network and strong voice in the local and international communities.

KKF have, together with Accountability and SAGIA, taken the initiative for SARCI. This is an index that is meant to mobilize a critical mass of companies to promote social development in the Kingdom. It is voluntary for companies to participate in this index; and during the first year 40 companies chose to participate. In the 2010 index the number of companies were doubled, which means that 80 companies participated in the index. This increased number of companies indicates that the interest and the knowledge of SARCI has increased significantly (" King Khalid Foundation,"2015). 


\section{Mll Macrothink}

International Journal of Human Resource Studies

ISSN 2162-3058

2015, Vol. 5, No. 2

The King Khalid Award for Responsible Competitiveness is one way of awarding responsible leadership in Saudi companies. The National Commercial Bank won the first price of the King Khalid Award in 2008, and did this partly because they have integrated the concept of CSR in the whole company and they were the first Saudi company to issue a world-class sustainability report. Beside this, they also have strong staff and supplier development programs that educate and affect other companies and individuals in Saudi Arabia. Ranked second was the Zamil Group. Its main differences from the other companies scoring high on the SARCI include environmental management systems, proactive staff development and product quality. Al-Fanar Company took the third place of the King Khalid Award for Responsible Competitiveness 2008. This was partly because of their work with partners to improve health and safety, the efforts of the company to combat counterfeiting, and focus on consumer satisfaction.

In 2010, the National Commercial Bank once again won the King Khalid Award for Responsible Competitiveness. The reasons for the selection of this bank as the winner in the second year includes continuous improvement since last year, promotion of corporate sustainability, environmental efforts and a high rate of female employment. Saudi Arabia is known for its charity and stewardship principles, but not much empirical work based on CSR constructs has been done. THE Jeddah Chamber of Commerce and Industry (JCCI) conferred on the National Commercial Bank (NCB) the "Saudi CSR in the category of Supporting Entrepreneurs and Small Enterprises" in appreciation of the bank's efficient contributions, initiatives and programs in this field in 2013 again. (http://www.saudigazette.com.sa/ index.cfm?

method=home.PrintContent\&fa=regcon\&action=Print\&contentid=20130421162252).

The award was presented for the first time by the JCCI and reinstated the fact that the bank had met the standards according to the Assessment Committee for the award. These criteria included NCB's leadership in developing distinct and leading programs to support 11,599 entrepreneurs and small enterprises and supporting the productive families with SR26 million dedicated to family training and financing the micro-projects. NCB's support to the entrepreneurs also included training, counsel, financing and promotion. It is also an appreciation of the bank's excellence and commitment in the field of corporate social responsibility in the Kingdom. The bank's contributions in the field of small and medium enterprises and entrepreneurs come through AlAhli programs for the small enterprises, AlAhli Productive Families Programs, and AlAhliInjaz, which present a bunch of diversified projects that aim at achieving the same goal, i.e. supporting the entrepreneurs. (What CRS means to NCB, from http://www.alahli.com/en-us/about-us/csr/Pages/About-CSR.aspx)

Saudi Basic Industries Corporation (SABIC) had in current times made commendable efforts. It received the GCC-CSR Award (April 1, 2014) for being the best performing organization according to CSR standards in the Gulf region. SABIC Vice Chairman and CEO had rightly explained that the company functioned as a social organization. The company has set several programs to develop the community and improve living conditions, besides initiatives to protect the environment and natural resources, and integrate the concept of sustainability in all its operations(Al Husseini,M., Arab News, 2012). 


\section{Discussion}

A strong and deeply embedded culture of giving already exists in the corporate sector in Saudi Arabia, especially in family-owned businesses with separate charity offices and family constitutions that define how the funds will be used for community welfare. The social infrastructure is mainly driven by cultural and religious causes, a fact that fosters a culture conducive for philanthropy. Company leadership has been spending huge amounts on charity for so long that now making the business case for CSR is about swaying them from their well-trodden path of ad hoc community initiatives towards strategic CSR, rather than convincing them to spend money in the first place. From 2008, the Sultan ibn Abdul Aziz Al-Saud Foundation formed a team for CSR as part of its charitable institution that aimed at developing society. The team's duty was to find methods to implement and help get the private sector involved in serving the social and charitable work and study international and regional programs and experiences to adopt successful CSR ideas (AlQasabi, 2008).

About forty years ago, when the West started debating in earnest the role of the corporation in society, Corporate Social Responsibility (CSR) was primarily focused on corporate charity and donations. Today, the debate is more concerned with strategic CSR, whereby companies search for ways to accommodate stakeholder interests in a manner that benefits profitability and long-term survival. In the Middle East, however, CSR is largely characterised by a charity mindset, and it is easy for an outsider to regard current CSR initiatives in the region as archaic: that Middle Eastern corporations are "lagging behind" in their thinking about CSR, and that the development of CSR in the Middle East is a matter of "catching up" to the West. (Ronnegard, D. (2013)

CSR has been misinterpreted as charity for so long that general perception of what it entails, in mind of the Saudi public, is far from the reality of what responsible business involves. This lack of understanding has slowed the spread of CSR, with companies focusing on one-off community initiatives in an effort to appease the general public.

Then, there is the role of government in the CSR agenda. While different ministries at different governmental levels deal with CSR, there is a need for a more strategic governmental umbrella for CSR that encourages, incentivizes and supports companies considering making the leap. A very important issue is the non-existent role of consumer-driven CSR. The consumer in KSA is woefully unaware of the implications of irresponsible business practices, so purchasing decisions are solely based on price or, at the very least, value for money. The only industries where the consumer is not as price-sensitive in my opinion are the healthcare and education industry. This is currently an impediment to the spread of CSR, as many companies do not see the tangible business benefits of being more responsible. There is also an urgent need for a Charter for implementing CSR programs. Dr.FaysalAlaquil, Director of Business Development \& Head of Corporate Social Responsibility at Construction Products Holding Company (CPC), discussed the need for a charter on corporate social responsibility. He said "CSR is a total commitment to enhance the conditions of our community,................."In his keynote address titled "The enforcement of the Cooperation Triangle in CSR" during the first day of the forum, he noted 
that "without a presence of a CSR charter, strategic CSR programs will not achieve its sustainable development goals." (http://www.saudigazette.com.sa/mobile/index.cfm? method=sphome. spcon\& contentid $=00000000160923)$.

Saudi Arabia fit very well into the international theoretical discourse of CSR. However, the main difference between the Saudi and international concept of CSR, as seen, is in the actual efforts of CSR. While the emphasis in the international discourse is on human rights, labor rights, the environment and anti-corruption, the focus of CSR efforts in Saudi Arabia is on developing the human and social capital in the country. This is related to the political challenges and goals in Saudi Arabia, and these points have been underpinned by the collaboration of all the actors of CSR in the Kingdom to assist in reaching these goals. This broad perspective of CSR, However, it is still not embraced by the wider business community in the kingdom, a fact that business leaders acknowledge. Nevertheless, there have been some organizations that have reinforced the CSR activities in recent years and enforced repeatedly a dominant player in community service and their commitment to conduct business ethically.

Research shows that in CSR, benchmarking can be a useful technique which companies can use in order to improve its CSR related activities. Important CSR dimensions can be identified and evaluated by observing how other organisations are doing in this area. The company can adopt the suitable aspects of the benchmarking and thereby change the company's strategies and policies. However this depends on the appropriate choice of the company and the receipt of the relevant information. The information received from the benchmarking can then be transformed and implemented into the company's business (Pojsek, 2010). Another successful strategy is the application of management control (Durden, 2007). Management control consists of all systems a manager use to ensure that the employees are acting in the organisation's best interest (Merchant and Van der Steda, 2012).

One cannot deny that one of the challenges with CSR is the contradiction of improving environmental, social and financial objectives at the same time. If managers feel monitored by financial targets in their work sphere, they would not be much willing and interested to involve themselves in social and environmental goals. Hence the managers should be given the chance to establish and follow non-financial goals too (Epstein, Buhovac \& Yuthas, 2010).

\section{References}

Adam, C., \& Zutshi, A. (2004). Corporate Social Responsibility: why business should act responsibly and be accountable. Australian Accounting Review, 14(3). http://dx.doi.org/10.1111/j.1835-2561.2004.tb00238.x

Alaquil: We need a charter on CSR (2013, April 11). Saudi Gazette. Retrieved from http://www.saudigazette.com.sa/index.cfm?method=home.regcon\&contentid=201304 11160923

Al-Husseini, M. (2012, June 26). The CEO of Advanced Electronics Company: Dr.Ghassan Al-Shebel. Alriyadh 
Al Qasabi, M. (2008, January 28). Corporate Social Responsibility. Arab News. Retrieved on 4 th Feb, 2015 from http://www.arabnews.com/node/308223

Ali, A.J., \& Al-Aali, A. (2012).Corporate Social Responsibility in Saudi Arabia. Middle East Policy Council, XIX (4). Retrieved on 15th Feb, 2015 from http://www.mepc.org/ journal/middle-east-policy-archives/corporate-social-responsibility-saudi-arabia. http://dx.doi.org/10.1111/j.1475-4967.2012.00558.x

Bondy, K., Moon, J., \& Matten, D. (2012). An institution of corporate social responsibility (CSR) in multi-national corporations (MNCs): Form and implications. Journal of business ethics, 111(2), 281- 299.http://dx.doi.org/10.1007/s10551-012-1208-7

Carroll, A., \& Shabana, K. (2010). The Business Case for Corporate Social Responsibility: A Review of Concepts, Research and Practice. International Journal of Management Reviews, 12 (1): 85-105.http://dx.doi.org/10.1111/j.1468-2370.2009.00275.x

Durdan, C. (2007). Towards a socially responsible management control system. Accounting, Auditing \& Accountability Journal, 21(5): 671-694.http://dx.doi.org/10.1108/ 09513570810872969

Gray, R., Kouhy, R., \& Lavers, S. (1995b). Methodology themes construction research database of social and environmental reporting by UK companies. Accounting, Auditing and Accountability Journal, 8(2), 78-101.http://dx.doi.org/ 10.1108/ 09513579510086812

Gustafson, J. (2002). Corporate social responsibility: Are you giving back or just giving away? Business: The ultimate resources. Perseus Publishing, pp. 291- 292.

Hussein, A., Najib, S., \& Bashar, Z. (2011). Arab Environment: Green Economy: Sustainable Transition in a Changing Arab World. Arab Forum for Environment and Development.

King Khalid Foundation (2015). King Khalid RCI Award. Retrieved from http://www.kkfeng.org/kingkhalid-awards.php

Lu, W., Wang, W., \& Lee, H. (2013).The relationship between corporate social responsibility and corporate performance: evidence from the US semiconductor industry. International Journal of Production Research, Business Source Premier, 51(19). http://dx.doi.org/10.1080/00207543.2013.776186

Merchant, K.A, \& Van der Stede, W. (2012). Management Control Systems; Performance measurement, evaluation and incentives. Prentice Hall, 3rd Edition.

National Commercial Bank (2015). What CRS means to NCB. Retrieved from http://www.alahli.com/en-us/about-us/csr/Pages/About-CSR.aspx

NCB wins the Saudi CSR Award (2013, April 20). Saudi Gazette. Retrieved on 5th March, 2015 from (http://www.saudigazette.com.sa/index.cfm?method=home. PrintContent $\&$ fa=regcon\&action=Print\&contentid=20130421162252)

Pojsek, R. B. (2010). Benchmarking to sustainability in four steps. Environmental Quality 
Management, 20(2): 87-94. doi:10.1002/tqem.20282 http://dx.doi.org/10.1002/ tqem.20282.

Reverte, C. (2009). Determinants of corporate social responsibility disclosure ratings by Spanish listed firms. Journal of Business Ethics, 88(2), 351-366. http://dx.doi.org/10.1007/s10551-008-9968-9

Ronnegard, D. (2013) .CSR in Saudi Arabia: Far Behind or another Path? INSEAD Knowledge. Retrieved on Mar.10.2015 from http://knowledge.insead.edu/csr/csr-insaudi-arabia-far-behind-or-another-path-2479\#QqwKEVUs0X1Mmbct.99

SABIC wins GCC-CSR's top social responsibility performer award (2014, April 13). Arab News. Retrieved on 10th April, 2015 from http://www.arabnews.com/news/554756)

Saudi Arabia: "Responsible Competitiveness Initiative" launched; helps business improve environmental, social performance. (2009). Business \& Human Rights Resource

Centre. Retrieved on Mar.11.2015, from http://www.business- humanrights.org/

Links/Repository/794338/link_page_view

Shehadi, R.T., \& Jamjoom, M. (2014). Corporate Social Responsibility's New Role in the Middle East. Strategy plus business. http://www.strategy- business.com/ article/00234? gko=b365d

United Nations Industrial Development Organization (UNICO, 2007). Building Linkages for Competitive and Responsible Entrepreneurship.

United Nations (2007). CSR and Developing Countries: What Scope for Government Action? Innovation Briefs, 1: pp.1-7. 